\title{
Characterization and Quantification of Municipal Solid Waste in Fátima, Ecuadorian Amazon Parish
}

\author{
Karel Diéguez-Santana ${ }^{1 *}$, Liliana Bárbara Sarduy-Pereira ${ }^{2}$, María De Decker ${ }^{3}$ \\ ${ }^{1}$ Facultad Ciencias de la Vida, Universidad Estatal Amazónica, Paso Lateral km 2 1⁄2 Via Tena, Puyo, Pastaza, Ecuador \\ ${ }^{2}$ Unidad Educativa Fiscomisional Cristóbal Colón, Parroquia Shell, Cantón Mera, Pastaza, Ecuador \\ ${ }^{3}$ Facultad Ciencias de la Tierra, Universidad Estatal Amazónica, Paso Lateral km 2 1⁄2 Via Tena, Puyo, Pastaza, Ecuador
}

Received: 16/09/2020

Accepted: 25/12/2020

Published: 20/06/2021

\begin{abstract}
Population growth and economic development have brought a high increase in the generation of municipal solid waste (MSW). The aim of this study is to determine the generation and characterization of solid waste in a rural parish of the Ecuadorian Amazon. A survey was applied and random sampling was carried out in 51 households. The results obtained in the study determined that the generation of waste is $0.51 \mathrm{~kg}$ cap- 1 day- 1 and the apparent density obtained was $191.86 \mathrm{~kg} \mathrm{~m}-3$. The different types of waste generated were characterized, the percentages obtained were $66 \%$ organic matter, $9 \%$ plastic, $7 \%$ glass, $7 \%$ of paper, $1 \%$ metals, $3 \%$ hygienic waste, $3 \%$ wood, $1 \%$ textiles and 3\% of other varied materials. In addition, a means analysis was performed with the nonparametric Wilcoxon Rank-sum test (Mann Whitney) using the STATA software version 12 . The results showed no significant differences ( $\mathrm{p}$ value $>0.05$ ) in the daily generation in both periods (April / September 2015). The values of the surveys carried out highlight a strong community acceptance towards recycling programs and separation at source. In addition, they request greater involvement of the authorities for the improvement of the current management of waste in the parish. Finally, more studies are recommended in cities and rural communities of Ecuador on the determination of the amount and composition of the waste, since there are many limitations of information, which affects the creation of effective waste management and disposal systems.
\end{abstract}

Keywords: Solid waste; generation per capita per day; waste composition; recycling; characterization; rural communities

\section{Introduction}

The economic and demographic growth of the countries have increased the rate of generation of solid waste, and created a new threat to the global sustainability agenda of the United Nations (UN) (1). New places previously with natural ecosystems have been converted into homes, infrastructures, or landfills, to meet human needs. Ecuador is not exempt from this, with one of the highest demographic rates in the region. There are several effects that can result from inadequate waste management from contamination of water, soil and atmosphere to high public health impacts (2), which implies a greater commitment in the generation of effective strategies to achieve a correct collection and elimination $(3,4)$. The management of urban solid waste (USW) in developing countries is a subject with considerable difficulties that faces great challenges with technical-economic limitations of municipal governments, together with political, legal, socio-cultural and environmental factors $(5,6)$. Difficulties such as waste collection services are a major problem for municipal authorities mainly in urban areas of low and middle income countries, where up to half of the population lacks them (7). Rural areas have not received as much attention as urban communities. Neglect problems with waste management in rural areas have been studied in several developing countries, for example, in Thailand Hiramatsu, Hara (8) evaluated the solid waste management in a district of the Nonthaburi province, and analyzed the interconnections between the local government, private sector entities, and the local community, to solve the lack of integrated management. Another study in Thailand, Manomaivibool, Srivichai (9) analyzed the effectiveness of community management in solid waste separation programs at the source in 18 pilot villages in Chiang Rai province.

In the same line, in Iran, several reports have quantified the rural solid waste generation, for example, Abdoli, Samieifard (10) in 21 scattered villages in the southern province of Bushehr. Moreover, Mohammadi, Amouei (11), in the 10 villages in the municipality of Babol (north of the country), and similarly Taghipour, Amjad (4) in the rural communities of the Khosrowshah district, Tabriz county. In Latin America and the Caribbean, there are also some studies in rural areas. For instance, from de Morais Lima and Paulo (12) in Brazil, they review the difficulties of waste collection (only $30 \%$ of the rural Quilombolas communities in Mato Grosso do Sul have access to the collection service), and the predominant scenario is the burning of waste. For their part, in Mexico, Taboada-González,

Corresponding author: Karel Diéguez-Santana, Facultad Ciencias de la Vida, Universidad Estatal Amazónica, Paso Lateral km 2 1/2 Via Tena, Puyo, Pastaza, Ecuador. Email: karel.dieguez.santana@gmail.com. O kdieguez@uea.edu.ec. ORCID ID: https://orcid.org/0000-00034064-0566. 
Aguilar-Virgen (13) and Taboada-González, Aguilar-Virgen (14) analyzed the amount and the type of domestic waste generated in two rural communities in Baja California, these works reflect the importance of studies on the generation of municipal solid waste (MSW) in developing countries rural communities and it shows how there are a recovery potential for some MSW components, although, more strategies from the municipal authorities are necessary.

The rapid urbanization processes and the high dependence of rural populations on industrialized products have led to an increase in the rural domestic solid waste generation (15). The rural areas present several difficulties in terms of the lack of management services, and when they exist they are inadequate and are limited to uncontrolled collection and disposal, consequently, the population majority does not have access to a waste collection service and final disposal is done in open dumps. Although, the domestic waste generation rate in developing countries rural areas is generally lower than that of developed countries (16), still, the lack of adequate infrastructure and weak solid waste management, together with the increases in the domestic waste generation, has brought an increase in environmental pollution and impacts on human health in rural areas $(8,15,17-19)$. On the other hand, solid waste characterization studies are an instrument of great importance for decision making, as mentioned (1), since it allows identifying the sources of component generation, estimating the recovery potential of materials, facilitate the design of equipment for processing, and comply with environmental laws and regulations of the waste management sector. The absence of data on the generation and composition of residues prevents the design and proper operation of solid waste management systems in communities (4).

Stakeholders in proper waste management are primarily local, municipal, and national governments (Ministries), private companies and contractors, non-governmental organizations (NGOs), households, and recycling companies (20). These actors are interrelated, and as mentioned by de Morais Lima and Paulo (12) in waste management in rural areas, the association and creation of groups are considered as a fundamental part of the decision-making process. In Ecuador, the Decentralized Autonomous Governments (GADs, acronyms in Spanish), according to the Republic of Ecuador Constitution have the exclusive competence to provide solid waste management services, so they must have the necessary infrastructures for policy formulation municipal environmental and the provision of the collection and management MSW service. Meanwhile, the Ministry of Environment of Ecuador (MAE), is in charge of the planning, regulation, and coordination of the National System of Environmental Management. Other institutional actors involved in comprehensive waste management are the health authorities (Public Health Ministry), and energy (Electricity and Renewable Energy Ministry) (21).

In civil society groups, they are grouped from Environmental Waste Managers, the general public, formal and informal recyclers. The first group is composed of people or associations that have an environmental license to manage waste (from collection, transport, treatment, recycling, and final disposal). The general public is mainly integrated by the domestic sector, and they are among the waste generators, the first link in the consumption chain. Another generating group is the business sector that, according to national regulations, must be governed under the Principle of Extended Producer Responsibility, and have waste recovery strategies with sufficient collection points and territorial coverage (22).

A very important civil society group is the waste pickers, which can be found both formal and informal. At the national level attempts have been made to establish commitments with these groups, but it is still difficult to regularize and organize it completely. Informal recyclers generally work in groups and divide areas of operations from the source, separating waste from garbage bags (placed in bins, sidewalks) before formal collection. While formal recyclers work mainly in groups, under agreements developed between government parties. At the national level, governance in solid waste management has sought to achieve good environmental quality and public health, within a framework of balance between the social, environmental, and economic dimensions. However, it is quite complex, since legal regulations exist (from the Constitution, Organic Codes, and regulations, with various regulatory aspects to protect the environment) but they are not always complied with, so it is necessary to strengthen the institutional framework and the application of legislation. Additionally, citizen participation in many of the environmental processes is limited. In the economic aspect, financially unsustainable management schemes still prevail. While in the case of social aspects, it is necessary to generate more effective campaigns to increase environmental awareness.

In Ecuador, the Decentralized Autonomous Governments (GADs) are responsible for the management of non-hazardous waste and sanitary waste generated in the areas of their jurisdiction (22). Since April 2010, the national government through the Ministry of Environment started the National Program for the Integrated Management of Solid Waste (Programa Nacional para la Gestión Integral de Desechos Sólidos, PNGIDS, acronym in Spanish), in order to solve the lack of information on the quantification of solid waste, and the operation and management plans. According to environmental statistics from the National Institute of Statistics and Censuses (INEC), in Ecuador, each inhabitant generates around 0.58 kilograms of solid waste daily, and in 2016, the collection was 12 thousand 897.98 tons of solid waste per day. Of these, $58.5 \%$ are organic waste and $41.5 \%$ are inorganic waste (INEC, 2017). Meanwhile, only $43 \%$ of Ecuadorian municipalities dispose of their solid waste in a sanitary landfill (INEC, 2017).

The Organic Environmental Code alludes to the importance of the integral management of solid waste for the reduction of environmental impacts associated with the management stages, based on the principle of hierarchy (prevention and minimization of its generation, separation at source, classification, recycling and temporary storage until collection, transport, storage and / or transfer, treatment, use and final disposal) (22). The SWM plans, according to article 565, of the Environment Organic Code Regulation, must be prepared by the municipal governments and presented for their approval, control, and monitoring to the National Environmental Authority. Among the criteria to be considered in its formulation is a diagnosis and presentation of waste management alternatives, with all the components of the system (including outreach, awareness, use, social inclusion, and training activities, among others) and the Program of monitoring and control (23). The rural environment according to the Integrated System of Social Indicators of Ecuador (Sistema Integrado de Indicadores Sociales del Ecuador- SIISE, acronyms 
in Spanish) are rural parishes, populated centers in peripheral areas of urban centers and dispersed populations, less than 5000 inhabitants (24). According to the last Population and Housing Census of Ecuador, $37 \%$ of Ecuadorians live in rural areas (around 5,392,713 inhabitants) (25).

The rural parish Fátima has a populated center with urban characteristics, streets, sidewalks and adjoining houses, but there are still scattered populated areas of the parish, with no access to the services of waste collection frequently. These services are provided by the Cantonal GAD of Pastaza, city of Puyo, in frequency three times weekly. Many of the homes are located on the slopes of rivers in the area which are tributaries of the Pastaza River. The access difficulty due to the condition of the roads or the frequency of rains prevents collection coverage. Additionally, in many sectors of the parish, micro-dumps have been observed on river slopes, streets, depressions of land and uninhabited areas, and the natural beauty of the natural environment has gradually deteriorated due to the accumulation of waste in places of tourist attraction.

There are no studies in the area regarding the sources of solid waste generation, or the amount and composition of these which hinders the design of management programs that aim to reduce the pollution caused by solid waste. Therefore, the objective of this document is to quantify and characterize the daily generation of solid waste from the rural parish of Fatima, in order to propose a more adequate waste management, reduce the impact of solid waste on the public health and the environment and improve the aesthetic appearance in the Fatima parish. The study also tries to assess the satisfaction of citizens with the waste management service provided and the perception of households towards the establishment of measures such as the separation of waste at the source and the implementation of a recycling program, a novel issue from cultural perception of the rural inhabitants of the Amazon.

\section{Materials and methods}

\subsection{Selection of the study area. Description of the study area. Study area}

The Fátima Parish is located in the Canton and Province Pastaza, in the Amazon Region of Ecuador. Located 7.42 kilometers from Puyo city to Tena, lies approximately $01^{\circ} 24^{\prime} 40^{\prime \prime}$ South Latitude and $78^{\circ} 00^{\prime} 00^{\prime \prime}$ West Longitude, at an altitude of $945 \mathrm{~m}$. a. s. 1 and it has an extension of $93 \mathrm{~km}^{2}$. It limits to the north with the Teniente Hugo Ortiz parish; to the south with the Puyo parish; to the east is the August 10 parish and finally to the west the Mera Canton, the temperature ranges from $18-24^{\circ} \mathrm{C}$ and the annual rainfall is 4000 to $5000 \mathrm{~mm}$ (26). Figure 1 shows the area of study and location of the parish. The Fátima parish, has 922 inhabitants, $51.8 \%$ men and the rest women. In the parish, there are three basic and secondary educational centers and a health sub-center. As for economic activity, most of the population is engaged in livestock activities (cattle, pigs, poultry) and agriculture (sugar cane, naranjilla, cocoa, taro, bananas, and cassava), followed by commercial activity, where there are small mainly gastronomic establishments and basic household goods.

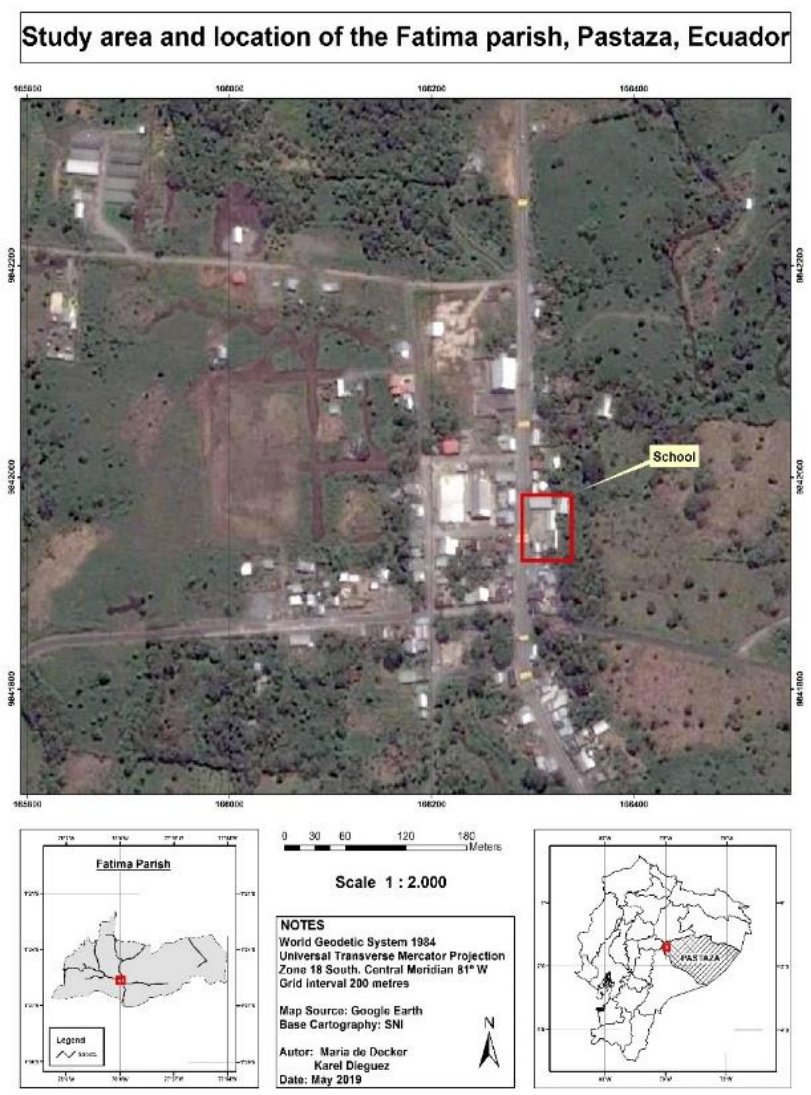

Figure1: Study area and location of the Fátima parish, Pastaza.

\subsection{Design of the sampling program. Household selection}

The random sampling method was used, recommended by the Pan American Health Organization / World Health OrganizationPAHO / WHO for the countries of the Latin America and the Caribbean Region (27). For the determination of the size of the sample and the selection of the households participating in the study, equation 1 was used, based on the information of the parish.

The statistical information of the National Institute of Statistics and Census of Ecuador was consulted, as well as the land use plan in order to know the conformation and the socioeconomic characteristics of the parish. According to data from the National Institute of Statistics and Census (INEC, Spanish acronym) (25), more than $90 \%$ of the parish has a low median socioeconomic status, so a non-stratified sample was taken. The sample size was calculated according to:

$n=\frac{\sigma^{2}}{\left(\frac{E}{Z}\right)^{2}+\left(\frac{\sigma^{2}}{N}\right)}$

where, $\mathrm{n}$ is number of samples, $\sigma$ is standard deviation of the variable production per capita of a household $\left(\mathrm{kg} \mathrm{cap}^{-1} \mathrm{day}^{-1}\right.$, according to CEPIS, $0.200 \mathrm{~kg} \mathrm{cap}^{-1} \mathrm{day}^{-1}$ ) (27), E is permissible error in the estimation of PCG ( $\mathrm{g} \mathrm{cap}^{-1} \mathrm{day}^{-1}$, according to CEPIS, $\left.0.050 \mathrm{~kg} \mathrm{cap}^{-1} \mathrm{day}^{-1}\right)(27), \mathrm{N}$ is total number of households or the defined stratum (196 house) (26), and $\mathrm{Z}$ is with reliability $95 \%$ : 1.96 . 


\subsection{The household survey}

In order to obtain information on the socio-economic characteristics of the residents, their attitudes toward internal management, elimination and separation of their waste, and willingness to participate in recovery and recycling programs, a survey was designed and administered for the selected households in the study area in the month of February 2015. In this case, it is part of a collaboration between University and local government. The University provided technical staff and the field phase, while the government supported logistics, waste transportation, and initial socialization with residents. To know the general perception of the residents about the solid waste collection system and the recycling practice, a questionnaire was elaborated following the Likert scale. The first part tried to assess the level of satisfaction with the system of solid waste collection operating in the parish (questions 1-3) and five (5) questions of considerations about the conditions and disposition for separation at the source and recycling. The evaluation was carried out in the following way: totally disagree (0), disagree (1), neutral (2), agree (3), totally agree (4).

In a second part, another section of the questionnaire was prepared, with the main problems caused by the grouped waste management system developed by the parish, with the options to be selected: very bad (0), bad (1), neutral (2), minor problem (3), and no problem (4). The answers were analyzed by frequency analysis and the Severity Index (SI) was also used, defined by (28) which was used in similar studies by (29). All the answers to the questions were shown on a scale of 0 to 4 points. Equation 2 shows the Severity Index (SI).

$S I=\frac{\sum_{i=0}^{4} a_{i} * x_{i}}{\sum_{i=0}^{4} x_{i}}(100 \%)$

where $\mathrm{a}_{\mathrm{i}}$ is the index of a class; constant expressing the weight given to the class; $x_{i}$ is the response frequency; $i=0,1,2,3,4$ and is described like: $\mathrm{x}_{0}, \mathrm{x}_{1}, \mathrm{x}_{2}, \mathrm{x}_{3}, \mathrm{x}_{4}$ are the response frequencies corresponding to: $\mathrm{a}_{0}=0, \mathrm{a}_{1}=1, \mathrm{a}_{2}=2, \mathrm{a}_{3}=3, \mathrm{a}_{4}=4$, respectively. The classification was considered as in $(29,30)$ : ao totally disagree $0.00 \leq \mathrm{SI}<12.5$, a 1 disagree $12.5 \leq \mathrm{SI}<37.5$, a 2 neutral $37.5 \leq \mathrm{SI}<62.5$, a3 agree $62.5 \leq \mathrm{SI}<87.5$, a 4 totally agree $87.5 \leq$ $\mathrm{SI} \leq 100$. The selection of households was random, if no one was at home in the household selected by the location of points previously made, the next homes were replaced by the absent family. The survey was conducted during a 3-day period during daylight hours directed to the wife or the mother whenever possible, since women more than men are usually responsible for waste management tasks in Ecuador.

Before starting the survey, all people involved in the project attended a training course to better understand the purpose of the survey, the importance of the hazards associated with working with waste materials, and the precise procedures for classifying and weighing these materials. Another aspect considered was the willingness to collaborate in the study in the two selected periods, to know the behavior of the parish in the two periods or defined climatic seasons of the tropical climate, wet season January-May, dry season June-December, popularly known like winter and summer respectively. April and September were selected within the periods.

\subsection{The waste characterization study}

The study of waste characterization was carried out, 30 days after applying the household survey, and the participants of the households interviewed were selected. The samples were collected door to door from the selected households and each one was enumerated to carry out the collection in an orderly manner during the 8 days of each study. Each day the empty bags were handed over to the owners of each of the homes selected for the deposit of the waste. The first day the residents of the selected homes were asked to collect all the waste they had from previous days, so that, during the 7 days of the study's validity, they only collect the garbage of 24 hours. It was suggested that they not change their habits or daily routine. The waste was always collected in the morning $8.00 \mathrm{am}$, before the departure for the works, etc. All the samples collected in each household were weighed with a Colometer electronic hand scale (accuracy \pm 0.01 $\mathrm{kg}$ in the range of $10-50 \mathrm{~kg}$ ), the samples in no case exceeded the maximum capacity of the balance.

For the determination of the Per Capita Generation (pcg) and the Daily Total of Solid Residues, the daily weight $\left(\mathrm{W}_{\mathrm{i}}\right)$ of the total bags collected during the days that the sampling lasted (excluding the first day) was used. The weight $\left(\mathrm{W}_{\mathrm{t}}\right)$ represents the total amount of daily waste generated in all households. Based on the data collected, the number of people per household was obtained and the total number of persons who participated in the sampling $\left(\mathrm{N}_{\mathrm{t}}\right)$ was determined. With all data collected, the average daily per capita generation of the sampled households was calculated according to equation 3 .

Per Capita Generation of waste $(\mathrm{pcg})=$
Total weight of waste $\left(\mathrm{W}_{\mathrm{t}}\right)$ $\frac{\text { Total weight of waste }\left(\mathrm{W}_{\mathrm{t}}\right)}{\text { Total number of persons }\left(\mathrm{N}_{\mathrm{t}}\right)}\left(\mathrm{kg} \mathrm{cap}^{-1}\right.$ day $\left.^{-1}\right)$

For the calculation of the total daily waste generation of the parish the value of the pcg was used and multiplied with the number of inhabitants of the whole parish Determination of waste generation rates for non-domestic sources. Theses was calculated according to equation 4-6.

Commercials waste generation rate $=$
Total weight of waste $\left(\mathrm{W}_{\mathrm{t}}\right)$
Total number of Commercials $\left(\mathrm{S}_{\mathrm{t}}\right)$
$\left(\mathrm{kg} \mathrm{day}^{-1}\right)$

School waste generation rate $=\frac{\text { Total weight of waste }\left(\mathrm{W}_{\mathrm{t}}\right)}{\text { Total number of school }\left(\mathrm{S}_{\mathrm{t}}\right)}$ $\left(\mathrm{kg} \mathrm{day}^{-1}\right)(5)$.

Street sweeping waste generation rate $=$ $\frac{\text { Total weight of waste }\left(\mathrm{W}_{\mathrm{t}}\right)}{100 \text { meter of street }\left(\mathrm{MS}_{\mathrm{t}}\right)}\left(\mathrm{kg} 100\right.$ meter street sweeping ${ }^{-1}$ day $\left.^{-1}\right)(6)$

Volume and density of waste: A cylindrical metal container with $210 \mathrm{~L}$ volume was used to determine the waste volume, which allowed calculating the specific weight of the not compacted waste and was reported in $\mathrm{kg} / \mathrm{m}^{3}$. The determination of the physical composition of the solid waste was made on top of a concrete surface, they were homogenized and divided into four parts, and separating the opposite parts as explained by the quartering method until obtaining a pile of approximately $50 \mathrm{~kg}$ in order to perform the classification of the considered fractions $\left(\mathrm{P}_{\mathrm{i}}\right)$ (27). Each of them was weighed and finally the corresponding percentage was calculated, by means of equation 7 . 
Percentage $(\%)=\frac{\mathrm{P}_{\mathrm{i}}}{\mathrm{W}_{\mathrm{t}}} * 100$

To avoid loss or increase of moisture in the waste stream by the sun or rain, the classification area was covered with a canvas. The categories for waste classification were selected based on Cantanhede, Monge (27) with modifications, based on the potential use and the majority presence of fractions. Being classified in: Organic Material, Plastic, Glass, Wood, Sanitary Waste, Metals, Paper, Textiles, Other Materials (Rubber, leather, etc.). From each of them, the percentage was calculated considering the weight of the component $\left(\mathrm{P}_{\mathrm{i}}\right) /$ the total weight of the waste collected in one day $\left(\mathrm{W}_{\mathrm{t}}\right)$. The result of the composition was obtained from the sum of the percentages of all the days of each component and between the days of study.

\subsection{Treatment of data from the waste characterization study}

In the first place, the Shapiro Wilk and Barttley Test was used to verify the normality and homoscedasticity of the collected data of waste generation during both periods. The data was not normally distributed; therefore, a nonparametric analysis of Wilcoxon Rank-sum (Mann Whitney) was performed. In a second analysis, a one-way ANOVA was performed with repeated measures to analyze the incidence of the "day of the week" on waste generation. The composition of the waste on the sampling days of April and September was compared by the t-test of independent samples and in cases where there was no normality or equal variance, the U-Mann Whitney nonparametric test. All the data were tabulated in Excel and the statistical program STATA version 12 was used for the statistical analyzes (31).

\subsection{Comparison with other waste characterization studies in rural areas}

A comparison with other waste characterization studies in rural areas was made. For this, the main databases and journals on the subject were consulted in Elsevier, Springer, Wiley, Taylor \& Francis, google scholar, among others. Only those with daily generation data per capita were considered. The other information that was considered for the comparison was the place of the study, the number of inhabitants, the apparent density, and the authors. In addition to the studies found, the composition of the waste and the management strategies used were consulted.

\section{Results and Discussion}

\subsection{Design of the sampling program. Household selection}

From the equation 1 and the data exposed in the methodology, the number of households to be sampled was calculated. The result was 45.75 , at this value $10 \%$ was added, with finally 51 households to be studied.

\subsection{The household survey}

The socio-economic characteristics obtained from the residents of the 51 households were reduced to the selected houses of the study. The survey was used to determine the habits and customs of the population related to the solid waste management. The aspects of internal management, elimination and separation of their waste, and willingness to participate in recovery and recycling programs were obtained from the responses of the questionnaire applied to the residents. The willingness to participate in the surveys was positive, although in the socializations the inhabitants were less receptive. In previous experiences they had not been satisfied with other environmental projects, but unlike (32), no participants wanted be compensated for the reconsideration of their waste. Bolaane and Ali (32) had asked the participants in their study to separate garbage into wet and dry waste, while in this study it was analyzed in its entirety as currently generated. Like Parizeau, Maclaren (7) the mood of the participants was adequate and many in the study area considered waste to be a problem in the community that is the responsibility of all. According to the household survey, the average family size in the study area is 4.6 persons, between an age range of 25 to 55 years. Table 1 reflects the feedback to the present solid waste collection system based on the calculation of severity indices.

Table 1: Feedback from respondents to the current solid waste collection system

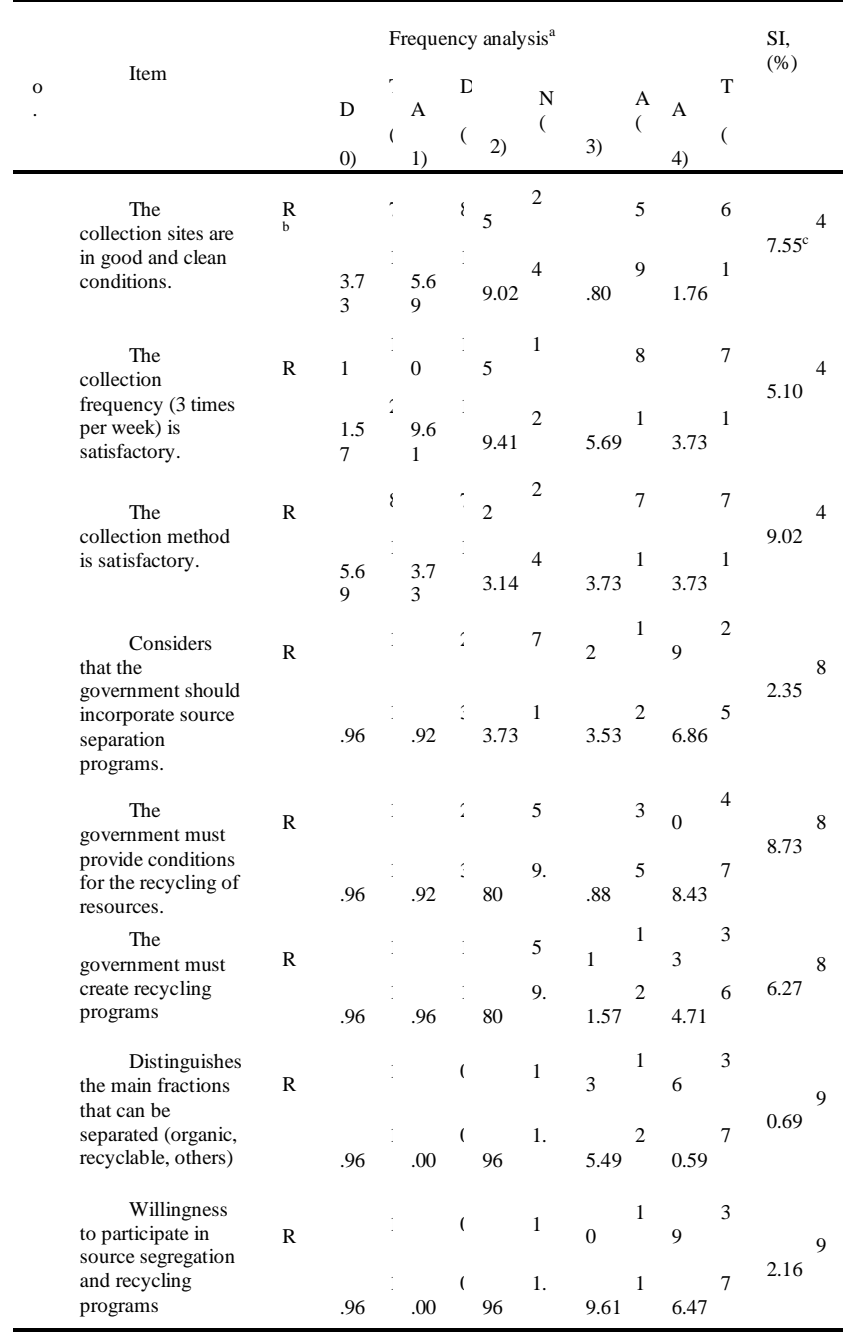

aTD totally disagree (0); DA disagree (1); N neutral (2); A agree (3); TA totally agree (4).

${ }^{b} \mathrm{NR}$, number of respondents, $\mathrm{P}$, percentage of respondents.

${ }^{\mathrm{c}}$ Calculation example, SI $=\frac{0 *(7)+1 *(8)+2 *(25)+3 *(5)+4 *(6)}{4 * 51} * 100=$ $47.55 \%$ 
The first three questions in the first section focused on the current collection system. The analysis shows that the opinion range, according to the severity index, was neutral, with $37.5 \leq \mathrm{SI}$ $<62.5$, therefore, as in other conclusions of previous studies, the authorities should pay more attention to the improvement of the existing collection system (29). Subsequent questions about the considerations about the conditions and provision for source separation and recycling have a strong community support because the opinion ranges between "agree" $62.5 \leq \mathrm{SI}<87.5$ and "totally agree" $87.5 \leq \mathrm{SI} \leq 100$, being the highest values towards the disposition of the population to participate in the recycling and separation at the source. The support of the authorities is an aspect that the inhabitants consider necessary, since 41 and 44 of the respondents (with severity indexes of $82.35,88.73$ and 86.27, Table1, Question 4-6) expect more support from the authorities for the creation and development of separation programs in the source and recycling, improve existing conditions, acquisition of container systems for separation by colors, covers and other materials that in several occasions do not have in homes for the activity to be effective.

With a Severity Index of 90.69, 49 respondents know the process of separating organic, recyclable, other materials (Table1, Question 7). When asking the respondents about the disposition towards the classification in the source, recycling and collaboration in strategies of use of solid waste generated in the parish, 49 respondents (96.08\% of the answers) and a Severity Index of 92.16 have willingness to participate in source segregation and recycling programs (Table1, Question 8). This was the highest Severity Index obtained and shows that there is a strong tendency towards the recovery of materials, recycling or separation at the source, since the inhabitants consider that it is a fundamental aspect in the improvement of waste management and therefore of the environmental conditions of the parish. Table 2 shows the dissatisfaction of the inhabitants due to the problems generated by the inadequate handling of the waste, since all the opinion ranges are between $12.5 \leq \mathrm{SI}<37.5$, which reflects that they do not agree. These values are more critical to those obtained in the study of Isa, Asaari (29) developed in communities of Nibong Tebal, Penang, Malaysia, which presented a neutral opinion range fluctuated between 32.5 and 53.8, while in this study they are inferior, which according to the opinion of the respondents, these aspects present great difficulties at the parish level. The public awareness factor is the most worrisome, which implies the necessary creation of a program that reinforces this aspect, so that greater collaboration and citizen participation is possible in solving the problems generated by waste in the current management system.

\subsection{The waste generation study}

In both periods, 51 households were sampled in a total of 14 days of study, the houses had a population of 207 inhabitants. The average daily weight of the collected waste ranged between
107.42 and $101.76 \mathrm{~kg}$. From these, the per capita generation of waste was obtained (daily weight of waste from each household, divided by the number of residents in each household), which was 0.519 and $0.492 \mathrm{~kg} \mathrm{cap}^{-1} \mathrm{day}^{-1}$, and on average $0.51 \mathrm{~kg} \mathrm{cap}^{-}$ 1 day $^{-1}$. Table 3 shows the total results obtained in the determination of the domestic SW generation rate, from the study, in the Fatima rural parish. The results of the Wilcoxon Rank-sum test (Mann Whitney), ( $p=0.7494)$ showed no significant differences (with $\mathrm{p}<0.05,95 \%$ confidence) in the daily generation in both periods (April/ September 2015). However, it was observed that the waste generation was slightly higher in the April 2015 period (average values of 107.42, compared to $101.76 \mathrm{~kg} \mathrm{day}^{-1}$ in September 2015). Additionally, the incidence of the day of the week on generation was analyzed. The analysis of variance ANOVA of one factor (with a 95\% confidence level, $\alpha=0.05$ ) from the means of both periods, showed that there are no significant differences with a value of $\mathrm{p}=0.6258$, higher than 0.05. However, in the chart of boxes (Figure 2) there are differences in the generation between days from Sunday to Saturday in both periods, with Wednesday being the day with the highest generation.

Table 2: Main incidences of the inadequate solid waste management in Fátima, Pastaza, Ecuador. Section-2

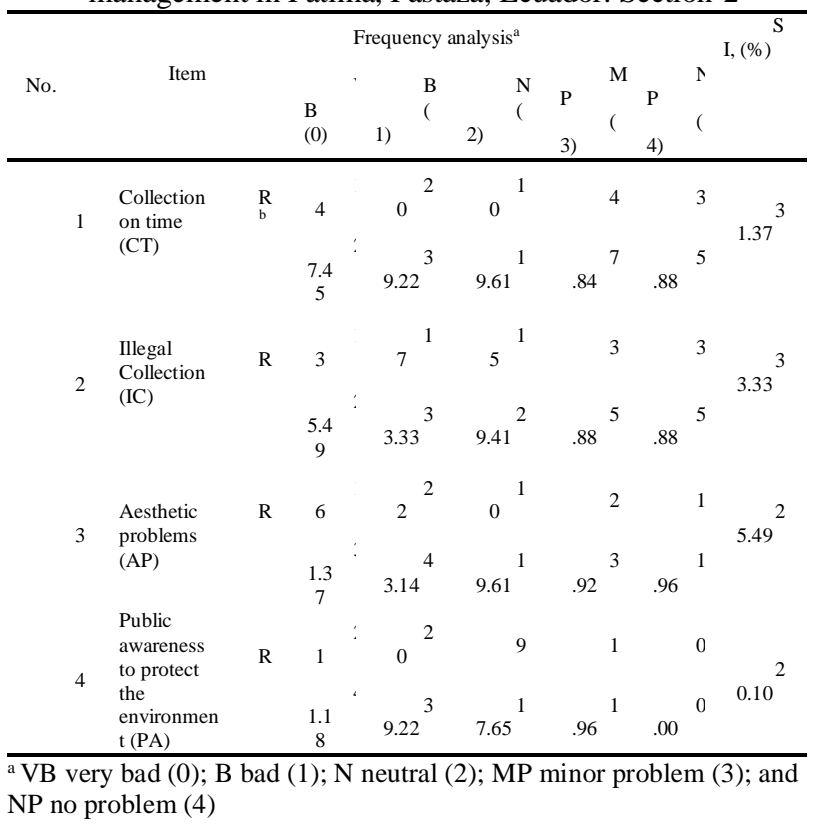

Table 3: Generation of household waste in study homes, Fatima parish

\begin{tabular}{|c|c|c|c|c|c|c|c|c|c|}
\hline \multirow[t]{2}{*}{ Study period } & Study days, $\mathrm{k}$ & & & & & & & $\begin{array}{l}\text { Average } \\
\text { weight, kg }\end{array}$ & $\begin{array}{l}\text { PCG, } \\
\mathrm{kg} \mathrm{cap}^{-1} \\
\mathrm{day}^{-1}\end{array}$ \\
\hline & 1 & 2 & 3 & 4 & 5 & 6 & 7 & & \\
\hline April/2015 & 129.45 & 92.87 & 90.24 & 157.1 & 94.08 & 87.8 & 100.4 & 107.42 & 0.519 \\
\hline September/2015 & 97.08 & 82.54 & 110.63 & 98.81 & 84.3 & 146 & 92.97 & 101.76 & 0.492 \\
\hline
\end{tabular}




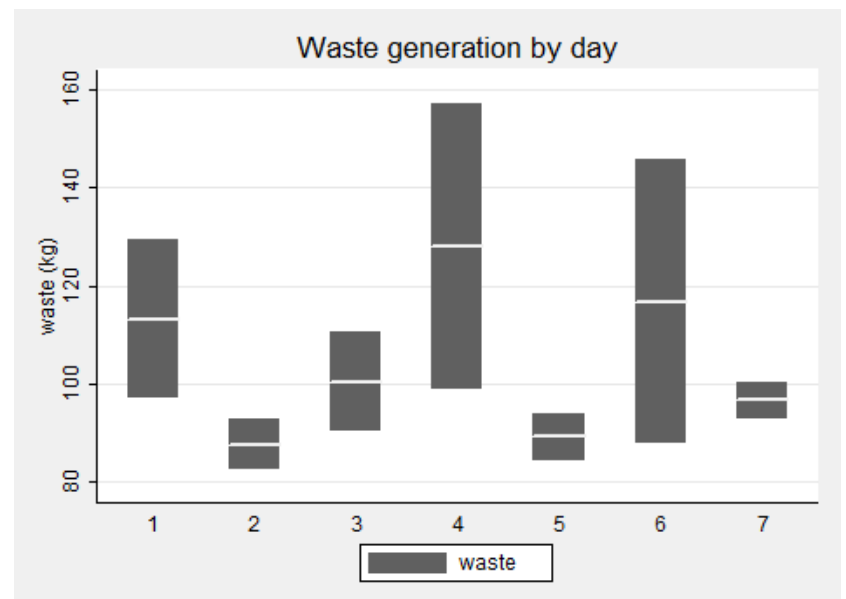

1- Monday, 2-Tuesday, 3-Wednesday, 4-Thursday, 5- Friday, 6Saturday, 7- Sunday

Figure.2: Average values of solid waste generation per day of the week

Figure 3 presents the frequency of the residue data ranges per capita of individual households. The values fluctuate between 0.32 to $0.75 \mathrm{~kg} \mathrm{cap}^{-1} \mathrm{day}^{-1}$. Most households (41 of 51 households) generate between 0.37 and $0.61 \mathrm{~kg} \mathrm{cap}^{-1}$ day $^{-1}$, being the most frequent value (11 households) between $0.4-0.5 \mathrm{~kg}$ cap ${ }^{1}$ day $^{-1}$. This coincides with the parish average daily generation per capita which is $0.51 \mathrm{~kg} \mathrm{cap}^{-1}$ day $^{-1}$. While in extreme values less than 0.37 and more than $0.7 \mathrm{~kg}$ cap- 1 day-1, there are only two households for each one of them, out of the 51 studied.

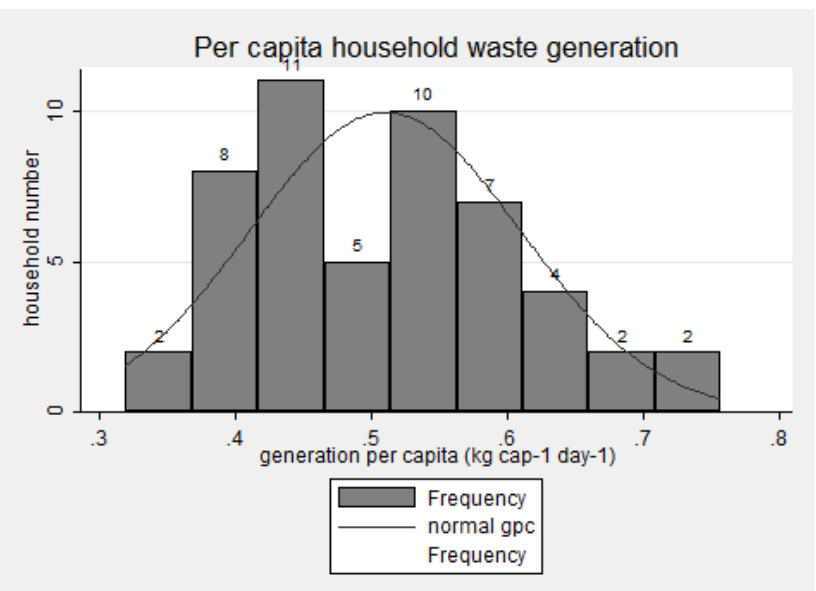

Figure 3: Frequency of per capita household waste generation in Fátima parish, Ecuador

The study included other generation sites that were also analyzed, table 4 presents the generation rates estimated from waste sampled in homes, businesses, institutions, and street sweeping. Considering the values of the waste generation in Table 4, the total waste generated per year in Fatima was calculated. Considering 922 inhabitants of the parish (863 inhabitants in the INEC Census, 2010 and a population growth rate of 1.32\%), the daily waste generation of households was $470.22 \mathrm{~kg}$, which represents $97.71 \%$. As for commercials-groceries, there are 8 small groceries shops, the daily generation is $6.16 \mathrm{~kg}(1.28 \%)$, while as institutions (schools) is $3.08 \mathrm{~kg}(0.64 \%)$ and street sweeping is done around of $600 \mathrm{~m}$, being $1.8 \mathrm{~kg}(0.37 \%)$, completing $481.26 \mathrm{~kg} \mathrm{day}^{-1}$ that are generated in the parish. These values reflect a predominance of waste generation in households in the parish and the percentages are similar to the values mentioned in Edjabou, Møller (17) (93\%) in Keitao, Africa.

Table 4: Estimation of waste generation rates of Fatima, Pastaza, Ecuador

\begin{tabular}{lllll}
$\begin{array}{l}\text { Source of } \\
\text { waste } \\
\text { generation }\end{array}$ & $\begin{array}{l}\text { Period, } \\
\text { April 2015 }\end{array}$ & $\begin{array}{l}\text { Period, } \\
\text { September } \\
2015\end{array}$ & $\begin{array}{l}\text { Anual } \\
\text { average }\end{array}$ & $\begin{array}{l}\text { Measured } \\
\text { unit }\end{array}$ \\
\hline Homes & 0.519 & 0.492 & 0.51 & $\mathrm{~kg} \mathrm{cap}^{-1}$ day $^{-1}$
\end{tabular}

Commercial

$\begin{array}{lllll}\text { s-Groceries } & 0.65 & 0.89 & 0.77 & \mathrm{~kg} \mathrm{day}^{-1}\end{array}$

\begin{tabular}{lllll}
$\begin{array}{l}\text { Schools } \\
\begin{array}{l}\text { Street } \\
\text { sweeping }\end{array}\end{array}$ & 3.25 & 2.9 & 3.08 & $\begin{array}{l}\mathrm{kg} \mathrm{day}^{-1} \\
\mathrm{~kg} 100 \mathrm{~meter}^{-1} \\
\mathrm{day}^{-1}\end{array}$ \\
\hline
\end{tabular}

From the rejected fractions of the cracking, the waste was weighed, and the volume occupied by the residues was determined to measure the apparent density of the residues. The average density was $191.68 \mathrm{~kg} \mathrm{~m}^{-3}$ (values of 197.17 and 186.18 $\mathrm{kg} \mathrm{m}^{-3}$ of the periods of April and September 2015 respectively) (See Table 4). This value is very similar to other results of studies, where the composition is similar, as for example Taghipour, Amjad (4) determined $211.31 \mathrm{~kg} \mathrm{~m}^{-3}$ in their study in Iran. On the other hand, there are values higher than those reported by Parizeau, Maclaren (7) in Siam, Cambodia which obtained $156 \mathrm{~kg}$ $\mathrm{m}^{-3}, 165.93 \mathrm{~kg} \mathrm{~m}^{-3}$ from Flores López (33) in Piura, Peru and Taboada-González, Aguilar-Virgen (13) in Baja California, Mexico that reported 145 and $123 \mathrm{~kg} \mathrm{~m}^{-3}$. While in Logroño canton (Ecuadorian Amazon) (34) obtained $293.14 \mathrm{~kg} \mathrm{~m}^{-3}$. These differences are given among other issues by the composition and humidity of the waste, as well as by the type of container. Although according to Parizeau, Maclaren (7) typical values reported for this type of waste is around $130 \mathrm{~kg} \mathrm{~m}^{-3}$, so the results are somewhat high in comparison. According to Al-Khatib, Monou (5) the presence of high amounts of food scraps and fruit peels (organic matter) have high moisture content and the density tends to be high, even up to $240 \mathrm{~kg} \mathrm{~m}^{-3}$.

Table 5 shows the per capita generation of solid waste from several previous studies. When compared to the average pcg value of $0.51 \mathrm{~kg} \mathrm{cap}^{-1} \mathrm{day}^{-1}$, it is very similar to other studies conducted for example in Palestine refugee camps $0.52 \mathrm{~kg}_{\text {cap }}{ }^{-1}$ day $^{-1}$ (35), or in Ecuador in Amazonia regions such as Bonilla Chango and Nuñez Vásquez (34) of $0.57 \mathrm{~kg} \mathrm{cap}^{-1} \mathrm{day}^{-1}$. Also slightly higher than studies conducted by the same methodology in Las Lomas District, Piura, Peru by Flores López (33) which obtained $0.46 \mathrm{~kg} \mathrm{cap}^{-1} \mathrm{day}^{-1}$. Daily per capita generation studies of household waste in rural communities in northwestern Iran Taghipour, Amjad (4) showed $0.259 \mathrm{~kg} \mathrm{cap}^{-1} \mathrm{day}^{-1}$, or Siem Reap, Cambodia $\left(0.34 \mathrm{~kg} \mathrm{cap}^{-1} \mathrm{day}^{-1}\right)(7)$, and $0.34 \mathrm{~kg} \mathrm{cap}^{-1} \mathrm{day}^{-1}$ in Kétao, Togo, West Africa (32). 
Table 5: Comparison of other characterization studies in different regions

\begin{tabular}{|c|c|c|c|c|}
\hline Place, country & $\begin{array}{l}\mathrm{pcg}, \\
\mathrm{kg} \\
\mathrm{cap}^{-1} \\
\text { day }^{-1}\end{array}$ & Population & $\begin{array}{l}\text { Density, } \\
\mathrm{kg} \mathrm{m}^{-3}\end{array}$ & Study \\
\hline $\begin{array}{l}\text { Siem Riep, } \\
\text { Cambodia }\end{array}$ & 0.34 & 85000 & 156 & (7) \\
\hline $\begin{array}{l}\text { Refugee } \\
\text { camps, } \\
\text { Tulkarem, } \\
\text { Tubas -Jenin, } \\
\text { Palestina }\end{array}$ & 0.52 & - & - & (35) \\
\hline San Quintín & 0.681 & 19800 & 145 & $(13,14)$ \\
\hline $\begin{array}{l}\text { Vicente } \\
\text { Guerrero, Baja } \\
\text { California, } \\
\text { México }\end{array}$ & 1.102 & 10632 & 123 & \\
\hline $\begin{array}{l}\text { Distrito de Las } \\
\text { Lomas, Piura, } \\
\text { Perú }\end{array}$ & 0.46 & 32339 & 165.93 & (33) \\
\hline $\begin{array}{l}\text { Logroño, } \\
\text { Morona } \\
\text { Santiago, } \\
\text { Ecuador }\end{array}$ & 0.57 & - & 293.14 & (34) \\
\hline $\begin{array}{l}\text { Tekanpur, } \\
\text { India, }\end{array}$ & 0.287 & 15000 & - & (36) \\
\hline $\begin{array}{l}\text { Rural } \\
\text { communities } \\
\text { in } \\
\text { northwestern } \\
\text { Iran }\end{array}$ & 0.259 & - & 211.31 & (4) \\
\hline $\begin{array}{l}\text { Kétao, Togo, } \\
\text { West África }\end{array}$ & 0.34 & 20000 & - & (17) \\
\hline $\begin{array}{l}\text { Mount } \\
\text { Kilimanjaro, } \\
\text { Tanzania }\end{array}$ & 0.6 & NA & NA & (37) \\
\hline $\begin{array}{l}\text { Chittagong, } \\
\text { Bangladesh }\end{array}$ & 0.25 & 3500 & NA & (3) \\
\hline $\begin{array}{l}\text { Nibong Tebal, } \\
\text { Penang, } \\
\text { Malaysia }\end{array}$ & 0,6 & & NA & (29) \\
\hline $\begin{array}{l}\text { Rural } \\
\text { Communities, } \\
\text { Juruá, Amazon } \\
\text { State, Brazil }\end{array}$ & 0.528 & 1152 & & (15) \\
\hline $\begin{array}{l}\text { Fátima, } \\
\text { Pastaza, } \\
\text { Ecuador }\end{array}$ & 0.51 & 922 & $\begin{array}{l}191.68^{\mathrm{a}} \\
197.17^{\mathrm{b}} \\
186.18^{\mathrm{c}}\end{array}$ & $\begin{array}{l}\text { This } \\
\text { study }\end{array}$ \\
\hline
\end{tabular}

${ }^{\mathrm{a}}$ Average value, ${ }^{\mathrm{b}}$ Value April $/ 2015,{ }^{\mathrm{c}}$ Value September/2015

\subsection{Determination of the physical composition of solid waste}

The evaluation of the physical composition is very important for the decision making of the authorities as regards the implementation of technologies for the solid waste treatment. Tables MS-1 and MS-2 show the results for the months of April and September 2015 of the characterization of the waste generated in the Fatima parish. When comparing the composition in the two periods, only the remains of food (organic matter) show significant differences $\mathrm{p}=0.0253$, the statistical results ( $\mathrm{t}$-test or
U-Mann Whitney) show values $\mathrm{p}>0.05$ (level 95\% confidence) for the rest of the characterized fractions. Figure 4 shows the summary of the general composition of the two periods.

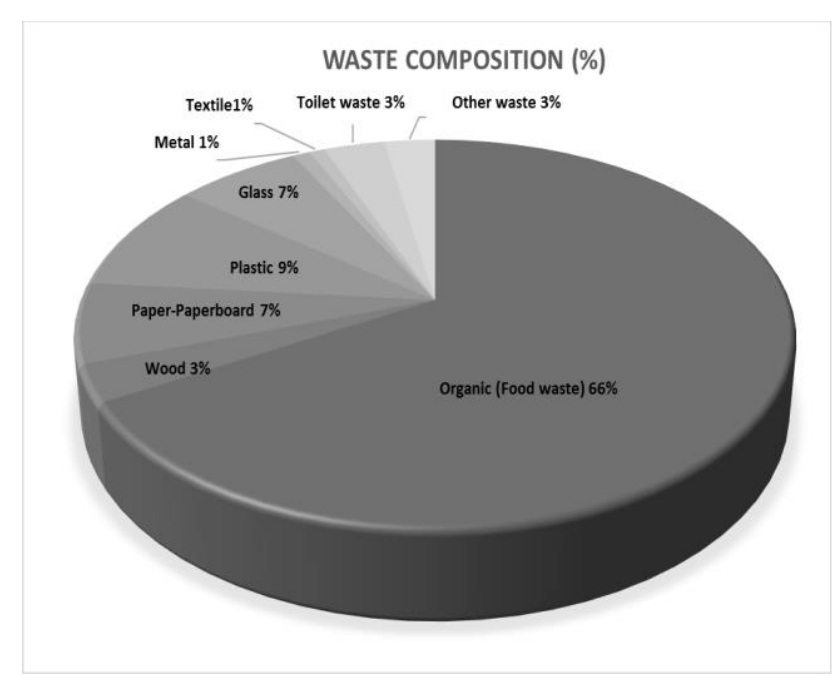

Figure.4: Composition of the general solid waste of Fatima

The results of the physical composition are very similar to those obtained in the previous studies of $(3,7,32-34)$ who get between $65-68 \%$ organic waste. These high values of food waste (organic matter) are common in rural areas where most of these organics are remains of food and other agricultural products and where the recycling strategies are inefficient or were not applicate at the time of conducting the solid waste studies. Additionally, as some authors suggest, they are common features in the behavior of solid waste generation in developing countries. The use of this component, through composting or vermicomposting could be a viable alternative to study in the parish. This can be done through home composting since most people have individual yards or gardens, with enough space, and local people are mainly engaged in agriculture. However, vector proliferation risks need to be controlled. In this sense, it is necessary for governments to carry out more training and socialization on these issues at the community level.

The recyclable items like glass, plastic and paper are covering almost $24 \%$ of the total garbage, very similar to $22 \%$ of the study by (4). Recyclables material can provide significant environmental and economic benefits, which implies the need for an effective environmental management proposal that allows the use of them. Furthermore, solid waste management cannot be seen as a problem, but rather as an opportunity, and several positive aspects can be involved from generation, collection, transport, treatment to final disposal $(38,39)$. About recycling, there is potential for inorganics, however, the authorities do not have areas to group the recyclable fractions, and there are economic limitations. In addition, the waste is mixed, which limits its collection in good hygienic conditions, so more environmental education is also required from separation at source. Stakeholders in parish waste management, from authorities, local actors, recyclers, could join forces and create agreements, alliances, and associations for waste management and improve the conditions of the materials recovery. It is important to formalize waste picker groups, to involve the 
population more in decision-making processes with integrated management. Options for inclusive recyclers could be coordinated and, as proposed in Article 232 of the Organic Environmental Code, local governments should provide capacity strengthening and training, mainly to popular and solidarity economy groups (22). A high composition of sanitary waste mainly composed of disposable diapers was also observed, with regard to other materials such as rubber, leather, traces of earth and other materials of varying composition so the value of only $3 \%$ could be considered a very low amount of this type of waste.

All analyzed community-level waste management alternatives require more environmental awareness among the local population. This component of environmental education and awareness must be reinforced, the Ministry of the Environment could support, like the University, because, although there have been some initiatives, such as education programs towards the integrated solid waste management to the population in some cities of the country, the case studies of separation processes at source do not become fully effective. It is also necessary that the political entities are the first ones to change their behavior because as Rodic and Wilson (40) suggest, the possibilities that citizens adopt new behavior patterns and become involved will be greater if local authorities exemplify the desired behavior in government buildings and surroundings.

\section{Conclusions}

The solid waste generated in the Fatima parish was characterized in two different periods of the year (April and September 2015). A total of 714 samples generated in 51 studied households were analyzed. In addition, the generation of an institution (rural school), street sweeping, and local commerce were quantified. In total $481.26 \mathrm{~kg}$ day $^{-1}$ were generated, households corresponded $470.22 \mathrm{~kg} \mathrm{day}^{-1}$ (97.71\%) and remaining to institutions, groceries and street sweeping. With respect to the seasonal influence in the generation and composition of residues, no significant differences were observed in both periods. The average waste generation rate of the Fatima parish was $0.51 \mathrm{~kg} \mathrm{cap}^{-1}$ day $^{-1}$ and the apparent density $191.68 \mathrm{~kg}$ $\mathrm{m}^{-3}$, similar values shown in other studies carried out in other regions of the world with similar characteristics. The classified fractions show that the majority composition is organic $(65 \%)$, and is suitable for implementing biological treatments such as household composting systems, because people have gardens, family garden and many are dedicated to agriculture, so who can use the compost obtained on site. However, more training and socialization on these issues is needed at the community level. In other hands, there are also valuation potentials of $24 \%$ of solid waste (recyclables, composed mainly of bottles and thick plastics, glass, paper, and cardboard), although it is necessary to establish investments and a value chain for the recovered materials, so greater environmental education for separation at the source can contribute to the recycling systems being able to receive the waste in better conditions and therefore reducing these fractions that today are sent directly to the Pastaza landfill. This process can be supported by parish waste management stakeholders, and authorities, local actors, recyclers, by joining efforts, creating alliances, and associations for the materials recovery that can be revalued. In fact, most Fatima survey respondents were willing to support recycling and segregation at the source. In addition, the process of formalizing waste picker groups, and involving the population more in decision-making processes can also contribute to improving waste management. At the national level, there is a regulatory framework for waste management, but its focus corresponds more to urban settlements, however, rural communities have continued to grow and also need more attention, the Ministry of Environment, could within the framework of the Program Center for the Integrated Management of Solid Waste enhance management in rural areas, and incorporate training programs with different stakeholders in the activity. Meanwhile, governments in their role of shared responsibility in all solid waste management services could influence the improvement of collection frequency and seek better conditions for use and final disposal. The community actors and the population, in general, should be ready to collaborate in the good environmental practices that may arise and create initiatives to improve the environment and show indicators of a clean parish that will end up giving other environmental and economic benefits to the environment. In addition, further studies on the determination of the amount and composition of waste in rural communities, as well as their waste management and disposal systems, so that MSW treatment and management approaches are more effective and are in line with local generation conditions.

\section{Aknowledgment}

The authors acknowledge the PROJECT "Gestion ambiental en la parroquia Fatima", that operated 2015-2016, between GADP Fatima and Universidad Estatal Amazónica. The authors also wish to thank Ing. Washington Patricio Chamorro and participant's students in field phase.

\section{Ethical issue}

Authors are aware of, and comply with, best practice in publication ethics specifically with regard to authorship (avoidance of guest authorship), dual submission, manipulation of figures, competing interests and compliance with policies on research ethics. Authors adhere to publication requirements that submitted work is original and has not been published elsewhere in any language.

\section{Competing interests}

The authors declare that there is no conflict of interest that would prejudice the impartiality of this scientific work.

\section{Authors' contribution}

All authors of this study have a complete contribution for data collection, data analyses and manuscript writing

\section{References (Vancouver style)}

1. Ayeleru OO, Okonta FN, Ntuli F. Municipal solid waste generation and characterization in the City of Johannesburg: A pathway for the implementation of zero waste. Waste Management. 2018;79:87-97.

2. Sharholy M, Ahmad K, Mahmood G, Trivedi RC. Municipal solid waste management in Indian cities - A review. Waste Management. 2008;28(2):459-67.

3. Sujauddin M, Huda SMS, Hoque ATMR. Household solid waste characteristics and management in Chittagong, Bangladesh. Waste Management. 2008;28(9):1688-95.

4. Taghipour H, Amjad Z, Aslani H, Armanfar F, Dehghanzadeh R. Characterizing and quantifying solid waste of rural communities. J Mater Cycles Waste Manag. 2015:1-8. 
5. Al-Khatib IA, Monou M, Abu Zahra ASF, Shaheen HQ, Kassinos D. Solid waste characterization, quantification and management practices in developing countries. A case study: Nablus district Palestine. Journal of Environmental Management. 2010;91(5):11318 .

6. Lohri CR, Camenzind EJ, Zurbrügg C. Financial sustainability in municipal solid waste management - Costs and revenues in Bahir Dar, Ethiopia. Waste Management. 2014;34(2):542-52.

7. Parizeau K, Maclaren V, Chanthy L. Waste characterization as an element of waste management planning: Lessons learned from a study in Siem Reap, Cambodia. Resources, Conservation and Recycling. 2006;49(2):110-28.

8. Hiramatsu A, Hara Y, Sekiyama M, Honda R, Chiemchaisri C. Municipal solid waste flow and waste generation characteristics in an urban - rural fringe area in Thailand. 2009;27(10):951-60.

9. Manomaivibool P, Srivichai M, Unroj P, Dokmaingam P. Chiang Rai Zero Waste: Participatory action research to promote source separation in rural areas. Resources, Conservation and Recycling. 2018;136:142-52.

10. Abdoli M, Samieifard R, Jalili GM. Rural solid waste management. Int J Environ Res. 2008;2:425-30.

11. Mohammadi A, Amouei A, Asgharnia H, Fallah H, Ghanami Z. A survey on the rural solid wastes characteristics in north Iran (Babol). Universal Journal of Environmental Research Technology. 2012;2(3):149-53.

12. de Morais Lima P, Paulo PL. Solid-waste management in the rural area of BRAZIL: a case study in Quilombola communities. J Mater Cycles Waste Manag. 2018;20(3):1583-93.

13. Taboada-González P, Aguilar-Virgen Q, Ojeda-Benítez S, Armijo C. Waste characterization and waste management perception in rural communities in Mexico: A case study. Environmental Engineering and Management Journal. 2011;10(11):1751-9.

14. Taboada-González P, Aguilar-Virgen Qi, Cruz-Sotelo SE, RamírezBarreto ME. Manejo y potencial de recuperación de residuos sólidos en una comunidad rural de México. Revista Internacional de Contaminación Ambiental. 2013;29(Sup. 3):43-8.

15. Bernardes C, Günther WMR. Generation of Domestic Solid Waste in Rural Areas: Case Study of Remote Communities in the Brazilian Amazon. Human Ecology. 2014;42(4):617-23.

16. Han Z, Liu Y, Zhong M, Shi G, Li Q, Zeng D, et al. Influencing factors of domestic waste characteristics in rural areas of developing countries. Waste Management. 2018;72:45-54.

17. Edjabou ME, Møller J, Christensen TH. Solid waste characterization in Kétao, a rural town in Togo, West Africa. Waste Management and Research. 2012;30(7):745-9.

18. Han Z, Ye C, Zhang Y, Dan Z, Zou Z, Liu D, et al. Characteristics and management modes of domestic waste in rural areas of developing countries: a case study of China. Environmental Science and Pollution Research. 2019;26(9):8485-501.

19. Zeng C, Niu D, Li H, Zhou T, Zhao Y. Public perceptions and economic values of source-separated collection of rural solid waste: A pilot study in China. Resources, Conservation and Recycling. 2016;107:166-73.

20. Guerrero LA, Maas G, Hogland W. Solid waste management challenges for cities in developing countries. Waste Management. 2013;33(1):220-32.

21. MAE. Programa Nacional para la Gestión Integral de Desechos Sólidos - PNGIDS ECUADOR Quito, Ecuador: Ministerio del Ambiente; 2014 [Available from: https://www.ambiente.gob.ec/programa-pngids-ecuador/.

22. Oficial R. Código Orgánico del Ambiente. Quito, Ecuador: Asamblea Nacional de la República de Ecuador; 2017. p. 92.

23. Oficial R. Reglamento del Código Orgánico del Ambiente. Quito, Ecuador2019.

24. SIISE. Sistema Integrado de Indicadores Sociales del Ecuador. Ficha Metodológica Quito, Ecuador2016 [Available from: http://www.siise.gob.ec/siiseweb/PageWebs/glosario/ficglo_areare.h tm.
25. Censo 2010 de población y vivienda en el Ecuador [Internet]. Instituto Nacional de Estadística y Censos. 2010 [cited March 25, 2018].

26. GADPRF. Plan de desarrollo y ordenamiento territorial parroquial, Fátima 2022. Pastaza, Ecuador; 2012.

27. Cantanhede A, Monge G, Sandoval Alvarado L, Caycho Chumpitaz C. Procedimientos estadísticos para los estudios de caracterización de residuos sólidos. Revista AIDIS de Ingeniería y Ciencias Ambientales: investigación, desarrollo y práctica. 2006;1(1).

28. Al-Hammad A-m, Assaf S. Assessment of Work Performance of Maintenance Contractors in Saudi Arabia. Journal of Management in Engineering. 1996;12(2):44-9.

29. Isa MH, Asaari FAH, Ramli NA, Ahmad S, Siew TS. Solid waste collection and recycling in Nibong Tebal, Penang, Malaysia: a case study. Waste Management \& Research. 2005;23(6):565-70.

30. Majid MZA, McCaffer R. Assessment of Work Performance of Maintenance Contractors in Saudi Arabia. Journal of Management in Engineering. 1997;13(5):91-

31. StataCorp. Stata Data Analysis Statistical Software: Release 12. College Station, TX: StataCorp LP; 2011.

32. Bolaane B, Ali M. Sampling household waste at source: Lessons learnt in Gaborone. Waste Management and Research. 2004;22(3):142-8.

33. Flores López JL. Estudio de caracterización de los residuos sólidos. Distrito de Las Lomas, Piura. 2009

34. Bonilla Chango MJ, Nuñez Vásquez DF. Plan de manejo ambiental de los residuos sólidos de la ciudad de Logroño. Sangolqui, Ecuador: Universidad de las Fuerzas Armadas (ESPE); 2012.

35. Al-Khatib IA, Arafat HA, Basheer T, Shawahneh H, Salahat A, Eid $\mathrm{J}$, et al. Trends and problems of solid waste management in developing countries: A case study in seven Palestinian districts Waste Management. 2007;27(12):1910-9.

36. Shah R, Sharma U, Tiwari A. Sustainable solid waste management in rural areas. Int J Theor Appl Sci. 2012;4(2):72-5.

37. Kaseva ME, Moirana JL. Problems of solid waste management on Mount Kilimanjaro: A challenge to tourism. Waste Management and Research. 2010;28(8):695-704.

38. Arteaga-Pérez LE, Segura C, Diéguez Santana K. Procesos de torrefacción para valorización de residuos lignocelulósicos. Análisis de posibles tecnologías de aplicación en Sudamérica. Afinidad. 2016; LXXIII(573):60-8.

39. Diéguez-Santana K, Casas-Ledón Y, Loureiro Salabarria JA, PérezMartínez A, Arteaga-Pérez LE. A life cycle assessment of bread production: A Cuban case study. Journal of Environmental Accounting and Management. 2020;8(2):125-37.

40. Rodić L, Wilson DC. Resolving Governance Issues to Achieve Priority Sustainable Development Goals Related to Solid Waste Management in Developing Countries. Sustainability. 2017;9(3):404. 